\title{
The Effect of History Teaching Supported by Dramatization Technique on Students' Achievement and Permanence Level
}

\author{
S. Gulin Karabagi \\ Okan Aydogan² \\ Gazi University, Ankara, Turkey. \\ Email:gkarabag@gazi.edu.tr Tel:+905053190578 \\ ${ }^{2}$ MoNE, Kirikkale, Turkey. \\ Email:okanaydogan55@gmail.com Tel:+905055362705
}

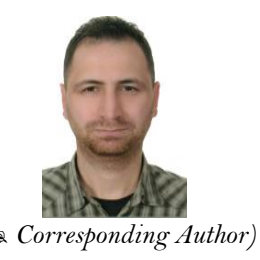

\begin{abstract}
The aim of this study is to determine the effect of history teaching supported by dramatization technique on students' success and permanence in history education in comparison with the traditional teaching. In this research, the semi experimental method which was practiced by pretest, post-test and permanence test were used and it was studied on two different student groups. One of them is control group tested with lecture method and the other one is experimental group tested by dramatization technique. Tested group consists of 63 students who studying in classes $10-\mathrm{A}$ and $10-\mathrm{B}$ of a vocational high school of Kırıkkale. This study is limited with units of "From Principality to State" in 10th grade students. During this experiment containing retention test were applied to experimental and control groups and the results were analyzed by the program SPSS 16.0. According to the findings obtained, in history lesson: there is a significant difference between the points of success and permanence of the group which is tested by dramatization technique and the group which is tested by teacher centered teaching. In other words, the dramatization technique, which actively involved students in the learning environment, was found to be more effective in the educational success of students and permanence of the information they learned compared to the teacher centered approach on the transfer of historical information to the students.
\end{abstract}

Keywords: History teaching, Achievement, Permanence, Drama, Dramatization technique, Lecture method.

Citation | S. Gulin Karabag; Okan Aydogan (2021). The Effect of History Teaching Supported by Dramatization Technique on Students' Achievement and Permanence Level. Asian Journal of Education and Training, $7(1): 36-45$

History:

Received: 16 November 2020

Revised: 18 December 2020

Accepted: 4 January 2021

Published: 21 January 202

Licensed: This work is licensed under a Creative Commons

Attribution 3.0 License $(\mathrm{ccc})$ E

Publisher: Asian Online Journal Publishing Group
Acknowledgement: Both authors contributed to the conception and design of the study.

Funding: This study received no specific financial support.

Competing Interests: The authors declare that they have no conflict of interests.

Transparency: The authors confirm that the manuscript is an honest, accurate, and transparent account of the study was reported; that no vital features of the study have been omitted; and that any discrepancies from the study as planned have been explained.

Ethical: This study follows all ethical practices during writing.

\section{Contents}

1. Introduction

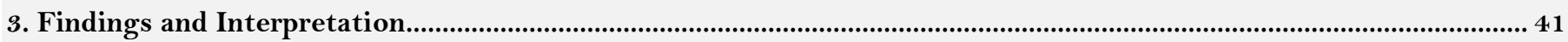

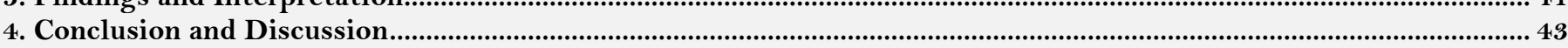

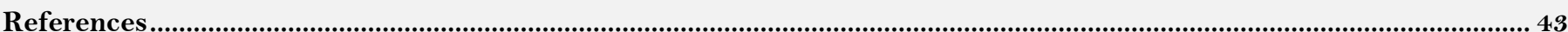




\section{Contribution of this paper to the literature}

This study determines the effect of history teaching supported by dramatization technique on students' success and permanence in history education in comparison with the traditional teaching.

\section{Introduction}

Educational activities, which include learning and teaching processes, have been structured with the influence of different experiences and opinions in the historical process. It is observed that educational activities were mostly formed based on behavioral and cognitive theories of the $19^{\text {th }}$ and $20^{\text {th }}$ centuries (Temizkan, 2010). As a result of this formation, teacher-oriented and rote-learning based approach towards education has emerged. The fundamental of this approach is the unilateral transfer of information to students and addressing everyone rather than individuals. This traditional approach has been questioned, considering that it is not effective in supplying people with the necessary knowledge and skills, and in guiding people in a world that is rapidly changing and evolving with technological advancements. Inevitably, people have started to seek for new methods in education. As a consequence of this pursuit, "student-oriented" approach towards education has emerged which allows students to construct information themselves, while considering the individual differences in students, and focusing on the skill teaching rather than memorizing information (Özpolat, 2013). In line with this understanding, active teaching methods and techniques have been initiated in educational institutions which leads students to use their mental abilities by giving them the responsibility of learning process, rather than traditional methods and techniques, such as direct instruction and question-answer (Açıgöz, 2011).

The questioning of educational understanding and the pursuit of new methods in the field of education in recent centuries have had an impact on the history teaching as well, since the traditional understanding based on teacher-oriented information transfer was criticized to be ineffective in history teaching. This traditional structure that is based on the transfer of dead information of the past to students has been criticized as of 1960 in the West, on the grounds that it does not help students struggling with life, and it was even questioned whether history lessons should be removed from the curriculum in these years (Booth, 1969; Price, 1968; Roberts, 1969; Seixas, 1993). Seixas (2000) stated that making students memorize history lessons as a real sequence of events in formal educational institutions is a myth or heritage (re-)construction rather than creating history, and this causes students to move away from history. In other words, students fall into the perception that history consists of reading, and hence, storing the names and event patterns in the mind. This misperception causes students to regard history lessons as based on memorization, difficult to understand and boring (Clara \& Tam, 2010; Mat \& Yue, 2013; Squire, 2004). However, since the 1970s, the purpose of history teaching has been disputed again from a Western perspective, and it has been emphasized that history teaching should help students cope with life as well as equipping them with national and moral values. Therefore, a transition was achieved from rote-learning-based history education, in which dry historical information is unilaterally transferred to students, to the understanding of "New History" which is student-oriented and focuses on teaching historiography skills (Demircioğlu, 2010; Karabağ, 2003). According to the understanding of "New History", the purpose of history teaching is not to unilaterally transfer the narratives and information produced by historians to students, but to succeed in equipping students with historical thinking skills such as interpreting historical documents and evidence, critical thinking, questioning, analyzing and synthesizing, chronological thinking, problem solving, versatile thinking, and feeling empathy. The new understanding of history dictates that history is a collection of active information and knowledge of real life that relates to both today and the future. For this reason, history teaching should not be a teacher-oriented and unilateral transfer of historical information to students. Instead, it should be based on a student-oriented and active approach. This approach will provide an important opportunity for history teachers to reach their educational goals in history lessons (Ata, 2006). In fact, many studies have shown that the active learning methods are effective in achieving desired goals and overcoming general problems in history teaching, such as rote-learning approach and general disinterest by students (Akça, 2012; Aydoğan \& Karabă̆, 2020; Çiftarslan, 2019; Işık, 2008; Karabağ, 2003; Karabağ \& Aydoğan, 2015; Karabă̆ \& Aydogan, 2020; Şahin, 2014; Yelkenci, 2019).

One of the active learning methods that can be used in history teaching is drama. In the Turkish dictionary (https://sozluk.gov.tr/), the meaning of drama is described as "the type of stage plays which pertains to a play and theater script written to be acted on the stage or to sad and tragic events, sometimes including their humorous aspects," and as the "acting used when talking about it as a subject to study or teach" in the Longman Dictionary (https://www.ldoceonline.com/). It is also defined as "a teaching method that facilitates the comprehension of connections among the events naturally consisting of improvisation, imagination, interaction and reenactment" (O’Neil \& Lambert, 1990).

\subsection{History Teaching and Drama}

The structure of history consisting of events and facts from the past creates an appropriate environment for employing the drama method. As a matter of fact, many drama pioneers such as Harriet Finlay-Johnson, Peter Slade and Dorothy Heathcote used historical themes in their drama activities. For example, Way (1967) the writer of the first theoretical book of drama called "Development through Drama", sees texts as an instrument for drama. Therefore, Way (1967) structured his first drama works over written texts. In fact, he himself wrote more than fifty children's plays for dramatization (Metinnam, 2011). Winifred Ward states that participants of drama could use an improvised play as well as a chosen poem, story or a fictional text in the creation. Ward defined these texts as tools to master drama activities and to elevate the improvisation element in drama (Adigüzel, 2012). Defining drama through children's plays, Slade (2005) likewise suggests that drama studies should be based on stories, even allowing students to produce their own scenarios. Additionally, Slade (2005) emphasized that students should act and improvise freely in the plays without having to follow the text blindly. Finlay-Johnson (1913) the first pioneer to use drama as a teaching tool, structured her first drama and teaching activities with the help of historical novels. She indicated that these activities, which would later be called drama, are effective tools in history teaching 
(Adıgüzel, 2012). Finlay-Johnson (1913) carried her activities beyond the dimension of enacting a given readymade dialogue by the students, to the point in which the students would prepare the dialogues of enactments. In this process, students created dialogues in accordance with historical reality by using historical sources such as historians (Kömür \& Kömür, 2016; Sapmaz, 2010). İsmayıl Hakkı Baltacıŏlu, one of the pioneers in associating history teaching with drama method in Turkey, also used historical subjects in his dramatic works. The inherent features of drama such as questioning, critical thinking, creating own narratives, effective decision making, analysis and synthesis capability, versatile and empathic thinking directly comply with historical thinking and historiography skills. In fact, Demircioğlu (2010) defines drama as one of the most significant teaching methods that can connect the past with the present in history lessons and help students be active and productive, and Stradling (2003) defines it as an important opportunity for students to develop their historical skills. It may be asserted that use of drama method in history teaching;

- Improves decision-making skill about historical events and facts.

- Improves problem-solving skills and assists coping with the problems of the current era by leveraging from historical problems (Başbuğ \& Bayramoğlu, 2018; Stradling, 2003).

- Enables the use of historical evidence and data (Tonga, 2014).

- Provides feedback to teachers regarding students' learning level and behavioral changes.

- Facilitates the learning of historical concepts and words (Dilek, 2007).

There are many studies that reveal the impact of the drama method on history teaching. Aylıç̧ (2001); Yurtalan (2005); Kartal (2009); Rüzgar (2014); Bingöl (2015); Saraç (2015); Pektezel and Uygun (2016); Schroeter and Wager (2017); Snelson, Lingard, and Brennan (2012); Pohl and Miller (2017); Otten, Stigler, Woodward, and Staley (2004)and Pektezel (2017) have made researches about the impact of drama method on the history topics of social study lectures, while Altıkulaç and Akhan (2015); Başbuğ and Bayramoğlu (2018); Akhan and Hayta (2014) and Güngör (2017) made researches on the impact of drama method on Ataturk's Principles and History of Turkish Revolution lectures. Also, while Firat (2017) explored the effectiveness of drama method in history teaching, Kurt (2018) explored the impact of drama method in teaching the 'Eurasia in the First and Middle Ages' curriculum unit for the 9th grade students. Additionally, Cochran (2015) explored the impact of role-playing technique in drama on historical thinking. In these researches, it was concluded that the drama method increases the student's success in history lectures and enables the permanence of historical information. In short, drama method has a positive impact on history teaching.

Even though the impact of drama method in increasing the quality of history lessons has been affirmed by many studies, history teachers hardly apply drama method in Turkey (Demirkan \& Saraçoğlu, 2016). Numerous reasons may be listed as to why history teachers do not use drama method, such as not being sufficiently equipped for drama, lack of drama texts, the intensity of the subjects, insufficient time for history lessons, the challenge of classroom control and classroom discipline during drama activities, and the required preliminary preparation for drama activities.

There are many tools that can be utilized to achieve desired goals in drama activities. The teacher chooses the most appropriate technique considering the structure of the subject, the drama environment and the characteristics of the group. At this stage, it is significant that the teacher is familiar with the chosen technique and has the relevant practical experience. This is because every technique has its specific rules and steps in the process (Adıgüzel, 2012). These techniques were listed as improvisation, role playing, the role-playing by the teacher, retrospective, still image, gossip circle, writing in role-playing, pantomime, role cards, teaser and dramatization in Ministry of National Education (MoNE, 2018) drama lesson curriculum.

\subsection{Dramatization Technique}

Dramatization, derived from the verb of dramatizing, is one of the concepts that is most confused with the concept of creative drama. In general terms, this confusion results from the fact that dramatization was derived from the verb of dramatizing, which has the same roots as drama; and it was used as a teaching method in Turkey in the past (Adıgüzel, 2012; Çoruh, 1950; Kavcar, 1985). However, dramatization is not a method by itself, it is rather one of the techniques used to perform drama activities, such as role playing and improvisation (Cakır, 2008; Güllü, 2009).

As a reflection of the close relation between drama and theater, the first drama studies in educational activities were structured through fictional texts written as stories or plays by playwrights or teachers. In other words, it may be asserted that educational drama was introduced with the dramatization technique at the beginning (Adıgüzel, 2012). This was because a guiding text was needed to overcome the timidity of the students who engaged in drama activities for the first time and to ensure that the subject proceeded within the desired educational limits. It was argued that as the students become more skilled in the drama activities, they should act more independently from the texts and emphasize the improvisational elements more. Therefore, dramatization is particularly significant among drama techniques. The dramatization technique become particularly significant in the disciplines that include certain event patterns, such as history. This is due to the fact that students should convey the event patterns in compliance with the historical reality. They are in need of guidance of a text to do this. As a matter of fact, when we review the drama activities of drama pioneers worldwide and in Turkey, we observe that the drama activities are generally based on the text, indicating the application of dramatization technique (Adıgüzel, 2012). For example, Baltacıŏlu, one of the prominent names in education in Turkey, had a stage built in the school garden during his duty at Şemsülmekatip, and he had his historical plays called "Italian Çorbacı, Village Teacher, Edirne Sector, Patriotic Heart, Flag, Gazas of Tiny Hüseyin, Murad Hüdavendigar, Martyrdom of Yavuz Sultan Selim” enacted by the students on this stage (Obuz, 2015).

Two different ways can be followed for the application of the dramatization method. In the first one, students are not provided with a written text, and the story or text is read by the teacher. Students try to reenact the process by sticking to the information and text communicated by the teacher (MoNE, 2014). In the second one, students are provided with a written text and asked to reenact it. However, students do not have to reenact the text 
exactly as given to them; they can express the parts in the text with a different discourse and body language without changing the flow (Kavcar, 1985). With regards to this aspect, dramatization differs from theater. Dramatization does not aim to make a visual presentation that will gain the applause of the audience, but to achieve outcomes in terms of learning by using it as a teaching technique. For this purpose, the teacher can apply the dramatization technique by associating it to different techniques of drama. For example, the teacher may have the students reenact the texts that contain specific problem cases and request them to discuss and generate ideas about the solution of the problem. Students may be asked to complement the given text through improvising by using incomplete texts as a starting point.

One of the most significant elements in the success of the dramatization technique is the text selection, since the most significant material of this technique is the text. Therefore, it is focused on the planning of the text rather than the imagination power of the students. The text should be appropriate for the level of students, and the characters in the text should be interesting. Furthermore, although it is not a basic requirement, the use of clothes and costumes suitable for the roles that will be reenacted in dramatization can contribute to the students' adaptation to the role more quickly, visually supporting the experience of actors and the audience, as well as the quality of these experiences (Adigüzel, 2012).

In the dramatization technique, the teacher plays more of an active guide and a determinant role compared to the other drama techniques. In this technique, the selection of the subject, the text to be reenacted, and proper distribution of the roles to the group members are ensured by the teacher. During reenactments, the teachers do not stay in the background; they can help the flow by interfering with the process and remind the students what needs to be said, if necessary (Adigüzel, 2012).

In short, it can be asserted that dramatization technique is a starting point where students take on a more active role for the improvisation in drama activities. Considering the educational benefits of dramatization technique, it can be said that there is a need for dramatization practice examples in order to guide the teachers.

In fact, an inquiry was made on databases such as YOK ACADEMIC, YOK THESIS, ULAKBİM and DERGIPARK in Turkey; and no study could be found which directly links dramatization technique with history teaching in Turkey, even if there are many studies setting forth the relation of fields such as Turkish language teaching (Kazıcı, 2008), foreign language teaching (Güllü, 2009; Umutlu, 2004) and geography teaching (Köseoğlu, 2006) with the dramatization technique. Hence, it can be said that there is a lack of study in literature. This study will address this shortcoming, serve as an example for researchers interested in the application of dramatization technique in history teaching and teachers who are in search of making history lessons qualified and interesting, and encourage them to apply the dramatization technique in history lessons.

\subsection{Objective of this Research}

The objective of this study is to identify the difference between the dramatization technique and other methods and techniques used in history lessons, and to set forth the impact of the dramatization technique in history teaching on the achievement of students and the permanence of learning.

In this study, two main problems are addressed:

- Is there a meaningful difference between the achievement scores of the group using the dramatization technique in the history lesson and the achievement scores of the group using other methods and techniques?

- Is there a significant difference between the permanence scores of the group using the dramatization technique in the history lesson and the permanence scores of the group using other methods and techniques?

\section{Method}

\subsection{Research Model}

This study compares the impact of dramatization technique against the impact of methods and techniques widely used in history teaching such as lecturing, question-answer on history teaching. The aim of this study is to prove the hypothesis that dramatization technique is more effective in the success of students and the permanence of their knowledge than other methods and techniques that are widely used. However, the controls required by real trial models cannot be fully provided in this process. For this reason, a quasi-experimental model with 'pretest/post-test/retention test' and control group was used in this study, which is used in cases where the controls required by real trial models cannot be provided or are not sufficient. In this model, there are two sample groups created through objective assignment. One of these groups is selected to be the experimental group and the other as the control group. The independent variables of the study are other methods and techniques applied with the dramatization technique, and the dependent variables as achievement and persistency (Karasar, 2014).

\subsection{Study Group}

The study group of the research consists of 63 students in 10/A (31 students) - 10/B (32 students) classes of a vocational high school in Kirıkkale.

\subsection{Data Collection Tools}

In this study, multiple choice achievement tests will be used as a measurement tool. Multiple choice tests are defined as tests that allow selecting the right answer of a question among given options (Baştürk, 2014). A measurement tool with 45 questions was prepared by the researcher, taking into account 9 acquisitions of the units "From Principality to State" in the 10th grade history teaching curriculum of the MoNE. 3 experts were consulted for their opinion of the tool to prove the validity of this measurement tool. Also, this measurement tool was applied to 196 students of different high schools in Kirıkkale, and the obtained data were analyzed through "TestAn" program; and hence, the reliability of the measurement tool, the discriminative power of test options and their difficulty values were set forth. Taking the expert opinions, the reliability of the test, the discriminative power of 
test options and their difficulty values into account, 15 questions were removed from the test, and the final measurement tool consisted of 30 questions.

According to measurement results, the average difficulty of the test was 0.634. Since this value is greater than 0.5 , the test is deemed at a sufficient level for educational activities. The reliability value (ALPHA) of the test was 0.833. This shows that the reliability of the test is at the ideal level.

\subsection{Process Steps}

In this study, the data was collected through pre-achievement tests. The following stages were followed during the development and implementation of the test.

1. First, a research was made on the relevant literature, and the sources on teaching with the dramatization technique were reviewed, and then "From Principality to State" unit in the $10^{\text {th }}$ grade curriculum was chosen.

2. Considering the acquisitions regarding the unit subjects in the $10^{\text {th }}$ grade, the drama texts that are appropriate for history teaching were written. Two drama experts and a historian were consulted for the written drama texts and necessary adjustments were made in the texts in line with their opinion.

Table-1. Unit acquisition relations of dramatization texts used in the study.

\begin{tabular}{|c|c|c|}
\hline Unit & Acquisition & Dramatization Activity \\
\hline \multirow{9}{*}{$\begin{array}{l}\text { Unit } 1 \\
\text { From } \\
\text { Principality } \\
\text { State }\end{array}$} & $\begin{array}{l}\text { 1.1. Comprehends the political situation of Anatolia, Europe and } \\
\text { the Near East at the beginning of the XIV } \text { th }^{\text {th }} \text { century }\end{array}$ & $\begin{array}{l}\text { World in the Early XIV }{ }^{\text {th }} \\
\text { century }\end{array}$ \\
\hline & $\begin{array}{l}\text { 1.2. Evaluates the factors affecting the evolution of the Ottoman } \\
\text { Empire. }\end{array}$ & $\begin{array}{l}\text { Interview with the } \\
\text { Ottoman }\end{array}$ \\
\hline & $\begin{array}{l}\text { 1.3. Describes the relation between the Ottoman Empire's } \\
\text { conquests in the Balkans and the settlement policy. }\end{array}$ & Settlement Policy \\
\hline & $\begin{array}{l}\text { 1.4. Evaluates the activities of the Ottoman Empire in Anatolia } \\
\text { with regard to ensuring Turkish political unity. }\end{array}$ & \\
\hline & $\begin{array}{l}\text { 1.5. Understands the impact of the Battle of Ankara on the } \\
\text { Turkish }\end{array}$ & $\begin{array}{l}\text { War of the Giants: Battle } \\
\text { of Ankara }\end{array}$ \\
\hline & $\begin{array}{l}\text { 1.6. Evaluates the political events that had an impact on the } \\
\text { strengthening of Turkish domination in the Balkans. }\end{array}$ & $\begin{array}{l}\text { Footsteps of the } \\
\text { Ottomans in the Balkans }\end{array}$ \\
\hline & $\begin{array}{l}\text { 1.7. Comprehends the basic characteristics of the Ottoman's } \\
\text { understanding of state and administration. }\end{array}$ & \\
\hline & $\begin{array}{l}\text { 1.8. Understands the basic characteristics of the Ottoman's } \\
\text { military organization structure in the XIV th and } \mathrm{XV}^{\text {th }} \\
\text { centuries. }\end{array}$ & $\begin{array}{l}\text { From Slavery to } \\
\text { Viziership: } \quad \text { Ottoman } \\
\text { Devshirme } \\
\end{array}$ \\
\hline & $\begin{array}{l}\text { 1.9. Understands the basic characteristics of the Ottoman } \\
\text { economy in the XIV th and } X V^{\text {th }} \text { centuries. }\end{array}$ & $\begin{array}{l}\text { The Story of an Idiom: } \\
\text { Shoe to be thrown to the } \\
\text { roof (to lose favor) }\end{array}$ \\
\hline
\end{tabular}

Note: $* \mathrm{p}>0.05$

3. The pre-test, which is a measurement tool developed by the researcher, was applied to the experimental and control groups in the research before lecturing the selected unit subjects.

Table-2. "Independent Groups t - Test" results regarding the pre-test scores of experimental and control groups.

\begin{tabular}{|c|c|c|c|c|c|c|c|}
\hline \multirow{3}{*}{ 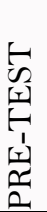 } & Group & $\mathbf{N}$ & $\mathbf{X}$ & SS & Sd & $\mathbf{t}$ & p \\
\hline & Control & 32 & 7.31 & 1.68 & \multirow[b]{2}{*}{61} & \multirow[b]{2}{*}{,659 } & \multirow[b]{2}{*}{, 512} \\
\hline & Experiment & 31 & 6.77 & 2.07 & & & \\
\hline
\end{tabular}

As shown in the Table 2 , the average pre-test score of the control group is 7.31 , whereas this score is 6.77 for the experimental group. There is a difference of 0.55 points between two groups. The results of " $t$ " test performed to set forth whether there is a significant difference between the average pre-test scores of two groups, " $\mathrm{t}$ " value is 0.659 and "* p" value is 0.512 . Based on this data, it was deduced that the means of the experimental and control groups are very close to each other. On the other hand, “* p" value is greater than 0.05 (* p>0.05). This shows that there is no significant difference between the pre-test results of these two groups. In other words, considering the pre-test scores of the experimental and control groups, it was observed that they were at an equivalent level to each other.

4. When the pre-test is finished, the subjects in "From Principality to State" unit was taught to the control group by using other methods and techniques such as lecturing, question and answer, brain storming and case study in line with daily and annual plans in the first semester of 2017-2018 academic period, whereas the same subjects were taught to the experimental group by using the dramatization technique.

5. The post-test, a measurement tool developed by the researchers, was applied to the experimental and control groups in the research after lecturing the selected unit subjects.

6. A permanence test was performed on the experimental and control groups after the implementation phase of the teaching models addressing the experimental and control groups of 10th grade students.

\subsection{Data Analysis}

SPSS 16 package program was used to analyze the data. Independent groups t-test was performed to determine whether the average pre-test, post-test and permanence scores of the groups differ from each other. Paired t-test was performed to determine whether there was a difference between the groups' average pre-test and post-test 
scores, as well as between their average post-test and permanence post-test scores. 0.05 was accepted as the level of significance in the interpretation of the results.

\section{Findings and Interpretation}

3.1. Findings Regarding the Difference Between Experimental Group's Pre-Test and Post-Test Scores

\begin{tabular}{|c|c|c|c|c|c|c|c|}
\hline \multirow{3}{*}{ 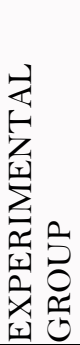 } & Test & $\mathbf{N}$ & $\mathbf{X}$ & SS & Sd & $t$ & p \\
\hline & Pre-test & 31 & 6.77 & 3.49 & & & \\
\hline & Post-test & 31 & 18.12 & 5.89 & 30 & -12.65 & , OOO \\
\hline
\end{tabular}

As shown in the Table 3, the average pre-test score of the experimental group, which is 6.77 , increased to 18.12 in the average post-test score after the lessons taught with the dramatization technique. This means that an increase of 11.35 points and $167 \%$ was achieved. Based on the results of the "t" test performed to identify whether there is a significant difference between the average pre-test and post-test scores of the experimental group, " $\mathrm{t}$ " value is 12.65, "* p" value is 0.000 and is less than $0.05(* \mathrm{p}<0.05)$. These data show that there is a significant difference between the experimental group's pre-test and post-test results. Thus, this is how we have found the answer for the first sub-problem of this study, which is "Is there a significant difference between the average pretest and post-test scores of the experimental group?".

\subsection{Findings Regarding the Difference between Pre-Test and Post-Test Scores of the Control Group}

\begin{tabular}{|c|c|c|c|c|c|c|c|}
\hline \multirow{3}{*}{ 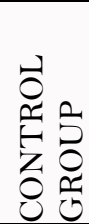 } & Test & $\mathbf{N}$ & $\mathbf{X}$ & SS & Sd & $t$ & $p$ \\
\hline & Pre-test & 32 & 7.31 & 2.96 & \multirow[b]{2}{*}{31} & \multirow[b]{2}{*}{-18.90} & \multirow[b]{2}{*}{,OOO } \\
\hline & Post-test & 32 & 14.46 & 4.48 & & & \\
\hline
\end{tabular}

As shown in the Table 4, the average pre-test score of the control group, which is 7.31, increased to 14.46 in the average post-test score, after the lessons taught by using other methods and techniques. This means that an increase of 7.15 points and $97 \%$ was achieved. Based on the results of the " $t$ " test performed to identify if there is a significant difference between the average pre-test and post-test scores of the control group, " $t$ " value is 18.90 , "* p" value is 0.000 and is less than $0.05\left({ }^{*} \mathrm{p}<0.05\right)$. These data show that there is a significant difference between the control group's pre-test and post-test results. Even if other methods and techniques were used; some information was transferred to the students and a certain level of learning occurred in the students as a result, it is expected to experience a significant increase in the scores of the control group. However, when these values were compared with the pre-test and post-test values of the experimental group, it was observed that the achievement level in the experimental group was higher than the achievement level of the control group. This reinforces that dramatization is a more effective method in history teaching. With these findings, we have found an answer for the second subproblem the study.

\subsection{Findings Regarding the Difference between Post-Test Scores of the Experimental Group and Post-Test Scores of the Control Group}

Table-5. "Independent Groups t - Test" results regarding the post-test scores of experimental and control groups.

\begin{tabular}{|c|c|c|c|c|c|c|c|}
\hline \multirow{3}{*}{ 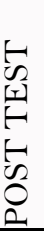 } & Group & $\mathbf{N}$ & $\mathbf{X}$ & SS & Sd & $\mathbf{t}$ & p \\
\hline & Control & 32 & 14.46 & 4.48 & & & \\
\hline & Experiment & 31 & 18.12 & 5.89 & 61 & -2.78 & ,007 \\
\hline
\end{tabular}

As shown in the Table 5, the average post-test score of the experimental group is 18.12 , whereas this score is 14.46 for the control group. There is a difference of 3.66 points between the average scores of the two groups, in favor of the experimental group. Based on the results of the " $t$ " test performed to identify whether there is a significant difference between the average post-test scores of both groups, "t" value is 61 , “* p" value is 0.007 and is less than $0.05(* \mathrm{p}<0.05)$. This finding shows that there is a significant difference between the post-test results of two groups, in favor of the experimental group in which the dramatization technique was applied. 
3.4. Findings Regarding the Difference between Achievement Scores of the Experimental Group and Achievement Scores of the Control Group

Table-6. "Independent Groups t - Test" results regarding the achievement levels of experimental and control groups.

\begin{tabular}{|c|c|c|c|c|c|c|c|}
\hline \multirow{3}{*}{ 点 } & Group & $\mathbf{N}$ & $\mathbf{X}$ & SS & Sd & $\bar{t}$ & $\mathbf{p}$ \\
\hline & Control & 32 & 7.15 & 4.48 & & & \\
\hline & Experiment & 31 & 11.35 & 5.89 & 61 & -4.37 & , OOO \\
\hline
\end{tabular}

As shown in the Table 6, the average achievement score of the experimental group is 11.35 , whereas this score is 7.15 for the control group. There is a difference of 4.2 points between the average scores of two groups, in favor of the experimental group.

Based on the results of the " $\mathrm{t}$ " test performed to identify whether there is a significant difference between the average achievement scores of both groups, "t" value is $-4,37$, “* p" value is 0.000 . This shows that there is a significant difference between the achievement results of two groups, in favor of the experimental group in which the dramatization technique was applied. In other words, dramatization technique was more effective than other methods and techniques used in teaching historical content.

\subsection{Findings Regarding the Difference between Post-Test Scores and Permanence Test Scores of the Experimental Group}

\begin{tabular}{|c|c|c|c|c|c|c|c|}
\hline \multirow{3}{*}{ 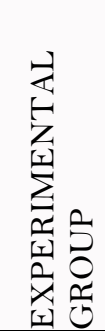 } & Test & $\mathbf{N}$ & $\mathbf{X}$ & SS & Sd & $t$ & $p$ \\
\hline & Post-test & 31 & 18.12 & 5.89 & & & \\
\hline & Permanence & 31 & 17.06 & 5.93 & 30 & 691 & ,495 \\
\hline
\end{tabular}

As shown in the Table 7, the average post-test score 18.12 in the experimental group decreased to 17.06 after the permanence test, and this means that a 1.06-point loss of achievement occurred.

Based on the results of the " $t$ " test performed to identify whether there is a significant difference between the average post-test scores and permanence test scores of the experimental group, " $t$ " value is 0.691 , “* $p$ " value is 0.495 . So, “* p" value is greater than $0.05(* \mathrm{p}>0.05)$.

This indicates that there was no significant loss of achievement in the experimental group. In other words, the permanence of the information taught in history lessons was ensured by supporting it with the dramatization technique.

\subsection{Findings Regarding the Difference between Post-Test Scores and Persistence Test Scores of the Control Group}

\begin{tabular}{|c|c|c|c|c|c|c|c|}
\hline \multirow{3}{*}{ 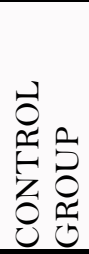 } & Test & $\mathbf{N}$ & $\mathbf{X}$ & SS & Sd & $t$ & p \\
\hline & Post-test & 32 & 14.46 & 4.48 & & & \\
\hline & Persistence & 32 & 12.90 & 4.63 & 31 & 1.298 &, 204 \\
\hline
\end{tabular}

As shown in the Table 8, the average post-test score 14.46 in the control group decreased to 12.90 after the persistence test, and this means that a 1.56 points loss of achievement occurred. Based on the results of the " $\mathrm{t}$ " test performed to identify whether there is a significant difference between the average post-test scores and persistence test scores of the control group, " $t$ " value is 1.298 , “* p" value is 0.204 .

These data indicate that there is no significant difference between the average post-test scores and the persistence test scores of the control group. In other words, in the control group, the persistence of the information was ensured in the history lessons taught using other methods and techniques. This is a normal situation, considering that there was a transfer of information to students with other methods and techniques as well.

\subsection{Findings Regarding the Difference between Persistence Test Scores of the Experimental Group and the Persistence Test Scores of the Control Group}

As shown in the Table 9, the average persistence test score of the experimental group is 17.06, whereas this score is 12.90 for the control group. There is a difference of 4.16 points between the average scores of two groups, in favor of the experimental group. Based on the results of the " $t$ " test performed to identify whether there is a 
significant difference between the average persistence test scores of both groups, " $t$ " value is -3.103, “* $p$ " value is 0.000 and is less than $0.05(* \mathrm{p}<0.05)$.

\begin{tabular}{l} 
Table-9. "Independent Groups $t$ - Test" results regarding the persistence test scores of \\
experimental and control groups. \\
\hline
\end{tabular}

These results show that there is a significant difference between the persistence test results of two groups, in favor of the experimental group in which the dramatization technique was applied. In other words, the dramatization technique used in the experimental group made a significant difference in the persistence of what was learned in comparison with the other methods and techniques applied in the control group.

\section{Conclusion and Discussion}

This study aims to show the impact of dramatization technique in history lessons on the achievement level of students and the persistence of their learning. Pre-test scores of the experimental group in which dramatization technique was used and that of the control group were compared, and no significant difference was found between two groups. This shows that the knowledge levels of these two groups about the subject were equal before the experiment. After the experiment process, the pre-test and post-test results of both groups were compared, and a meaningful difference was found in both groups. In the light of the data obtained from the post-test results and achievement levels of the students, it was observed that there was a significant difference, in favor of the experimental group. In other words, the dramatization method proved more successful than other methods and techniques in teaching the subject. After three months of this experiment, both groups went through a persistence test and the persistence scores of two groups were compared. Hence, it was affirmed that there is a significant difference, in favor of the experimental group in which the dramatization technique was applied. That is to say, a more effective learning environment was created in the lessons taught with the support of the dramatization technique, compared to other methods and techniques; and the loss of achievement was less.

When the related literature is examined, it is seen that studies on dramatization focus more on language development. In these studies, it was concluded that the dramatization technique positively affected students 'motivation and participation in the course according to methods such as question-answer and narration, thus contributing positively to students' success' (Cakır, 2008; Greenfader \& Brouillette, 2013; Koç, 2009; Umutlu, 2004). In their interdisciplinary study where they combined literature and history teaching (Kornfeld \& Leyden, 2005) concluded that historical stories were written and enacted in the classroom environment had a positive effect on history teaching. Likewise, Cruz and Murthy (2006) stated that their work based on the fact that students animated fiction diaries on American history and short monologues about historical characters revealed effective results in history teaching. All these results coincide with the result that the dramatization technique obtained in this study positively affects the academic success of students in history teaching.

In summary, the findings of this study show that there is a meaningful difference between the achievement and persistence scores of the experimental group in which the dramatization technique is applied and that of the control group which uses other methods and techniques. This demonstrates that the dramatization technique, which actively includes students in the learning environment, was more effective in helping the students acquire knowledge and ensuring the persistence of the information learnt compared to other methods and techniques. The following recommendations can be listed based on this result:

- For the success of drama activities in educational environment, it is of utmost importance that teachers are adequately equipped in this respect. Historians as well as history teachers can write dramatization texts; however, in order to do this, they should have enough knowledge of the technique. For this purpose, onthe-job trainings can be given both to facilitate the process and to encourage them to write text.

- There is not enough number of texts associated with historical content for drama activities in history lessons. As a matter of fact, the researchers could not find any dramatization texts appropriate for the acquisitions during the application of the study. Preparing drama texts regarding each subject at different grade levels will make it easier for teachers to apply the dramatization technique.

- When the history curriculum for 2018 is examined, it is seen that there is no statement associated with drama. It is considered that the curriculum guidance is also important for teachers to apply active methods and techniques. Therefore, such methods and techniques that can guide teachers should be included in the history curriculum.

- When the history textbooks are examined, it is observed that the activity examples of using drama method in history lessons are not sufficient. Structuring some subjects in the textbooks directly through drama activity will ensure that drama method will be more actively used in history lessons.

\section{References}

Açıkgöz, K. (2011). Active learning. Izmir: Bilis.

Adıgüzel, Ö. (2012). Creative drama in education. Ankara: Naturel.

Akça, N. (2012). Practice of historical reeanactment in the course of Turkish Revolution and Kemalism at the 11th grade of the high school: An action research. Unpublished PhD Dissertation, Gazi University Institute of Educational Sciences, Ankara.

Akhan, N. E., \& Hayta, N. (2014). A sample practice in the revolution history and Kemalism, republic of Turkey: An analysis of a period: Nutuk. Kastamonu Education Journal, 22(3), 1049-1076. 
Altıkulaç, A., \& Akhan, N. E. (2015). The effect of using the creative drama method and the six thinking hat technique on student success and attidudes in 8th grade revolution history and Kemalism lesson. Kırşehir Faculty of Education Journal, 11(3), 225-247.

Ata, B. (2006). Nisan. Reflective inquiry tradition and constructivism approach in social studies education. Paper presented at the III. Constructivism and its Reflections in Education Symposium, Private Tevfik Fikret Schools, Izmir.

Aydoğan, O., \& Karabağ, Ş. G. (2020). The effect of history teaching supported by educational computer game on student's chronological thinking and space perception skills. International Journal of New Approaches in Social Studies, 4(1), 106-130.Available at: https://doi.org/10.38015/sbyy.734552.

Aylıkçı, E. (2001). The Effects of dramatization method on internalization and assimilation of knowledge in learning social sciencess. Unpublished MA Dissertation, Marmara University Institute of Educational Sciences, Istanbul.

Başbuğ, S., \& Bayramoğlu, A. (2018). Student views on the Republic of Turkey revolution history and Kemalism with creative drama method. Creative Drama Journal, 13(1), 53-68.

Baştürk, S. (2014). Multiple choice tests. S. Baştürk (Ed.), Measurement and evaluation in education (pp. 119-154). Ankara: Nobel.

Bingöl, K. T. (2015). Effect of drama tecnique in primary school 4th class social studies lesson on academic success, attitude and permenance. Unpublished MA Dissertation, Erzincan University Institute of Social Sciences, Erzincan.

Booth, M. (1969). History betrayed. UK: Longmans. Green and Co Publishing.

Cakır, B. (2008). Effectiveness of creative drama method in kindergarten Turkish language activities. Unpublished MA Dissertation. Ondokuz Mayıs University Institute of Social Sciences, Samsun.

Çiftarslan, N. (2019). Teaching T.C. History of revolution and Kemalism at sth grade level through evidence based learning approach: A phenomenological study. Unpublished MA Dissertation, Marmara University Institute of Educational Sciences, İstanbul.

Clara, H. C. Y., \& Tam, F. (2010). Learning Chinese history through digital game. Paper presented at the IEEE International Conference on Digital Game and Intelligent Toy Enhanced Learning, Kaohsiung, Taiwan.

Cochran, D. J. (2015). Drama and history: Teaching historical thinking through role-play. Unpublished MA Dissertation, University of Wisconsin, Wisconsin.

Çoruh, S. (1950). Dramatization in schools. Istanbul: Öğretmen Dergisi.

Cruz, B. C., \& Murthy, S. A. (2006). Breathing life into history: Using role-playing to engage students. Social Studies and the Young Learner, $19(1), 4-8$.

Demircioğlu, İ. H. (2010). Student-centered approaches in history teaching. Ankara: Anı.

Demirkan, Ö., \& Saraçoğlu, G. (2016). Views of Anatolian high school teachers about teaching methods and techniques they use in class. The Journal of International Lingual, Social and Educational Sciences, 2(1), 1-11.

Dilek, D. (2007). Learning and the development of thinking in history lessons. Ankara: Nobel.

Finlay-Johnson, H. (1913). The dramatic method of teaching (2nd ed.). London: James Nisbet Co. Limited.

Firat, Ö. (2017). The effectiveness of drama method in teaching history. Unpublished MA Dissertation, Ataturk University Institute of Educational Sciences, Erzurum.

Greenfader, C. M., \& Brouillette, L. (2013). Boosting language skills of English learners through dramatization and movement. The Reading Teacher, 67(3), 171-180.Available at: http://dx.doi.org/10.1002/TRTR.1192.

Güllü, M. (2009). The effects of dramatization in foreign language teaching. Unpublished MA Dissertation. Beykent University Institute of Social Sciences, Istanbul.

Güngör, M. (2017). Turkish republic history for sth class. Creative drama effect in concept of revolution history and Ataturk Turkish course. Unpublished MA Dissertation, Inonu University Institute of Educational Sciences, Malatya.

Işı, H. (2008). Effects of using document in history teaching to students historical thinking skills and successes. Unpublished PhD Dissertation, Gazi University Institute of Educational Sciences, Ankara.

Karabağ, Ş. G. (2003). The historical empathy as a teachable and a cognitive skill. Unpublished PhD Dissertation, Gazi University Institute of Educational Sciences, Ankara.

Karabağ, Ş. G., \& Aydoğan, O. (2015). The effect of history teaching with game method on students' achievement and retention level. Turkish History Education Journal, 4(1), 67-88.Available at: https://doi.org/10.17497/tuhed.185623.

Karabă̆, Ş. G., \& Aydogan, O. (2020). Teaching history with computer games. Ankara: Iksad.

Karasar, N. (2014). Scientific research method. Ankara: Nobel.

Kartal, T. (2009). The effect of drama method on students? Achievement in the teaching of ancient history units a 6th grade social studies course. Unpublished MA Dissertation. Selcuk University Institute of Social Sciences, Konya.

Kavcar, C. (1985). Dramatization in formal education. Education and Science, 1O(56), 32-41.

Kazıc1, E. (2008). In Turkish lessons at the second part of the elementary education, effectiveness level of dramatization method at the teaching of the idioms and proverbs. Unpublished MA Dissertation, Selcuk University Institute of Social Sciences, Konya.

Koç, K. (2009). Comparison of dramatization and creative drama in the seventh grades Turkish lesson of the elementary schools. Unpublished MA Dissertation. Ondokuz Mayıs University Institute of Social Sciences, Samsun.

Kömür, E., \& Kömür, A. İ. (2016). A case study; the method of teaching history by plays of Harriet Finlay-Johnson. Research and Experience Journal, 1(1), 28-35.

Kornfeld, J., \& Leyden, G. (2005). Acting out: Literature, drama, and connecting with history. Reading Teacher, 59(3), $230-238$.

Köseoğlu, İ. (2006). Using dramatization as a problem-solving strategy in geography. Unpublished MA Dissertation, Marmara University Institute of Educational Sciences, Istanbul.

Kurt, C. (2018). The effect of teaching the 9th grade "Eurasia in the first and the middle ages" unit through drama on academic achievement. Unpublished MA Dissertation, Gazi University Institute of Educational Sciences, Ankara.

Mat, Z. N. A., \& Yue, S. W. (2013). Design and evaluation of history digital game-based learning (DGBL) software. Journal of Next Generation Information Technology, 4(4), 9-24.

Metinnam, İ. (2011). Investigation of Brian way's apprehension of drama in the creative drama field. Unpublished MA Dissertation, Ankara University Institute of Educational Sciences, Ankara.

MoNE. (2014). Child development and education drama practices. Ankara: MoNE Publishing.

MoNE. (2018). Drama lesson curriculum. Ankara: MoNE Publishing.

O’Neil, C., \& Lambert, A. (1990). Drama structures. A practical handbook for teachers. London: Hutchinson Publishing.

Obuz, Ö. (2015). Right to Heat Baltacioglu's world of thought. Unpublished PhD Dissertation, Anadolu University Institute of Social Sciences, Eskisehir.

Otten, M., Stigler, J. W., Woodward, J. A., \& Staley, L. (2004). Performing history: The effects of a dramatic art-based history program on student achievement and enjoyment. Theory and Research in Social Education, 32(2), 187-2 12.

Özpolat, V. (2013). The place of student-centered education approach in teachers' professional priorities. National Education Journal, 43(200), $5-27$.

Pektezel, B. (2017). Using drama while teaching history subjects in social studies lesson. Unpublished MA Dissertation, Usak University Institute of Social Sciences, Usak.

Pektezel, B., \& Uygun, K. (2016). Historical journey with Gokturks. Research and Experience Journal, 1(1), 1-27.

Pohl, B., \& Miller, D. M. (2017). Appreciative reflections of a social studies teacher: Seeing history through literacy instruction. English in Texas, $47(1), 10-15$.

Price, M. (1968). History and danger. History, 53(179), 342-347.

Roberts, M. (1969). Contemporary problems of sixth form history. History, 54(182), 393-405.

Rüzgar, M. A. (2014). 6th grade social studies curriculum unit on the silk road Turkish drama in the treatment process of the concept of the migration impact on student achievement. Unpublished MA Dissertation, Giresun University Institute of Social Sciences, Giresun.

Şahin, A. N. E. (2014). Effects of using analodgy based activities in history teaching on students' successes, attitudes and historical thinking skills. Unpublished PhD Dissertation, Gazi University Institute of Educational Sciences, Ankara. 
Sapmaz, C. (2010). An evaluation of Harriet Finlay-Johnson's approach to drama within her general view on education. Unpublished MA Dissertation, Ankara University Institute of Educational Sciences, Ankara.

Saraç, A. (2015). Effect of drama method on success, permanence and attitude in social studies lesson. Unpublished MA Dissertation, Balıkesir University Institute of Social Sciences, Balikesir.

Schroeter, S., \& Wager, A. C. (2017). Blurring boundaries: drama as a critical multimodal literacy for examining 17 th century witch hunts. Journal of Adolescent and Adult Literacy, 60(4), 405-413.Available at: https://doi.org/10.1002/jaal.585.

Seixas, P. (1993). Parallel crises: History and social studies curriculum in the USA. Journal of Curriculum Studies, 25(3), 235-250.

Seixas, P. (2000). Schweigen! die kinder! or, does postmodern history have a place in the schools? In P. Stearns, P. Seixas, and S. Wineburg (Eds.), Knowing, Teaching and Learning History: National and International Perspectives (pp. 20-39). New York: New York University Press.

Slade, P. (2005). Child play: Its importance for human development. London and Philadelphia: Jessica Kingsley Publishers.

Snelson, H., Lingard, R., \& Brennan, K. (2012). The best way for students to remember history is to experience it!": Transfor ming historical understanding through scripted drama. Teaching History, 148, 28-36.

Squire, K. (2004). Replaying history: Learning world history through playing Civilization III. PhD Dissertation.

Stradling, R. (2003). How to teach 20th century European history. (trans. A. Unal). Istanbul: Tarih Vakfi.

Temizkan, M. (2010). The effect of Turkish language course II which arranged according to student-centered learning on attitudes towards talking skill. National Education Journal, 4O(187), 86-103

Tonga, P. (2014). Journey into history with creative drama. Istanbul: Cinius.

Umutlu, A. (2004). The effect of the dramatization method on the teaching foreing language and teaching adjectives by the dramatization method. Unpublished MA Dissertation. Ataturk University Institute of Social Sciences, Erzurum.

Way, B. (1967). Development through drama. London: Longman Publishing.

Yelkenci, Ö. F. (2019). Enabling the students creative historical thinking skill in history teaching: An action research. Unpublished PhD Dissertation, Marmara University Institute of Educational Sciences, Istanbul.

Yurtalan, E. (2005). Make use of the drama method on the subject matters of history of the 6th grade social knowledge course. Unpublished MA Dissertation, Gazi University Institute of Educational Sciences, Ankara. 